\title{
The Value of Magnetic Resonances Imaging in Localized Lipoatrophy
}

(iD Amber EKER ${ }^{1}$, iD Pembe Hare YİĞiTOĞLU², id Aslı Feride KAPTANOĞLU33

${ }^{1}$ Near East University Faculty of Medicine, Deparment of Neurology, Lefkoşa, Northern Cyprus TC

${ }^{2}$ Near East University Faculty of Medicine, Deparment of Physical Medicine and Rehabilitation, Lefkoşa, Northern Cyprus TC

${ }_{3}^{3}$ Marmara University Faculty of Medicine, Department of Dermatology, İstanbul, Turkey

ABSTRACT

Localized lipoatrophy usually presents as isolated or multiple, atrophic, depressed areas which are commonly found in the proximal part of extremities. We report a case with idiopathic localized lipoatrophy and want to emphasize the role of magnetic resonance imaging in the evaluation of atrophic lesions.

Keywords: Lipoatrophy, idiopatic localized, magnetic resonance imaging

\section{Case Report}

Here, we report a case who had idiopathic localized lipoatrophy and want to emphasize the role of magnetic resonance imaging (MRI) in the evaluation of atrophic lesions. Informed consent was taken from the patient.

A 48-year-old female who was a physical education teacher was admitted to our clinic with a 16-year history of slowly progressive atrophy on her anterolateral part of right tight. She described a tingling-like sensation on the atrophic area at the beginning. She also realized a slight atrophy on her left tight in addition to the sensation for the last one year. She did not have an occult trauma or injection history to this atrophic area. Her physical examination revealed only an artophic area on her right tight without any skin coloration pathology. There was no muscle weakness and sensory deficit. Her electromyography (EMG) test was also normal both in upper and lower extremities. Lumbar MRI did not reveal any pathology. Lower extremity MRI (Figure 1 and 2) showed localized atrophy in only adipose tissue on the anterolateral part of her right tight. There was no muscle pathology in the neighborhood of the atrophy. Her blood tests including complete blood count, thyroid functions, infection markers and vasculitic screen were all normal.

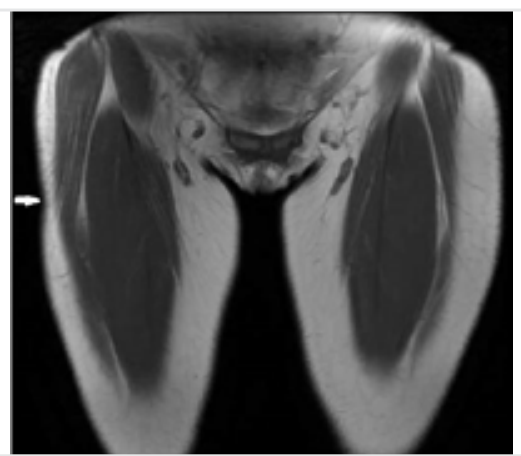

Figure 1. Lower extremity magnetic rezonans imaging, coronal T2 weighted sequences showed localized atrophy in adipose tissue on the anterolateral part of right tight

Address for Correspondence: Amber EKER, Near East University Faculty of Medicine, Deparment of Neurology, Lefkoşa, Northern Cyprus TC

Phone: +90 3926751000 E-mail: ambereker@yahoo.com ORCID ID: orcid.org/0000-0001-9997-4662

Cite this article as: Eker A, Yiğitoğlu PH, Kaptanoğlu AF. The Value of Magnetic Resonances Imaging in Localized Lipoatrophy. Bezmialem Science 2019;7(3):245-6. 


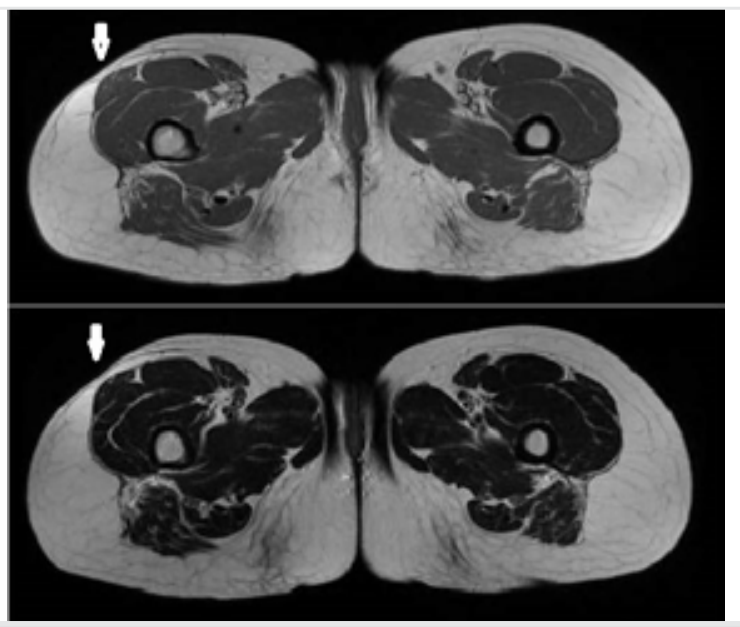

Figure 2. Lower extremity magnetic rezonans imaging, axial T2 weighted sequences showed localized atrophy in adipose tissue on the anterolateral part of right tight

Localized lipoatrophy usually presents as isolated or multiple, atrophic, depressed areas which are commonly found in the proximal part of extremities. Lesions usually have no overlying skin changes but secondary skin hypopigmentation may also accompany. The idiopathic localized lipoatrophy is a rare syndrome and its cause is unknown. Localized lipoatrophic syndromes may be associated with subcutaneous and intradermal injections $(1,2)$. Also some authors reported co-occurrence with connective tissue disease (3). Additionaly, in the recent years, researches have emphasized the role of recurrent microtraumas in semicircular localized lipoatrophy (4).

There was no occult trauma, injection history in our patient and we excluded all the systemic conditions that may have caused lipoatrophy. But, our patient was a physical education teacher and she made intense exercises for 35 years. We can speculate that the microtraumas may have caused lipoatrophy. However, there is no explanation to why some people are affected by microtraumas and others are not affected.

Lipoatrophy in the extremities may be misinterpreted as neuromuscular disorders Detailed neurological examination and
EMG test are helpful to discriminate a neuromuscular disorder from a lipoatrophy.

Additionaly, in recent years, MRI has commonly been used in diagnosis of the neuromuscular disorders and it may also help the evaluation of adipose tissue (5). MRI of lower extremities, a noninvasive method, showed us that the atrophy was only in adipose tissue under the depressed areas in our patient. MRI can help us to evaluate not only the depressed area, but also all the extremity, the contralateral side and all the body.

\section{Ethics}

Informed Consent: Informed consent was taken from the patient.

Peer-review: Externally peer-reviewed.

\section{Authorship Contributions}

Concept: A.E., P.H.Y., Design: A.E., P.H.Y., A.F.K., Data Collection or Processing: A.E., P.H.Y., A.F.K., Analysis or Interpretation: A.E., P.H.Y., A.F.K., Literature Search: A.E., Writing: A.E., P.H.Y., A.F.K.

Conflict of Interest: No conflict of interest was declared by the authors.

Financial Disclosure: The authors declared that this study received no financial support.

\section{References}

1. Dahl PR, Zalla MJ, Winkelmann RK. Localized involutional lipoatrophy: a clinicopathologic study of 16 patients. J Am Acad Dermatol 1996;35:523-8.

2. Yamamoto T, Yokozeki H, Nishioka K. Localized involutional lipoatrophy: report of six cases. J Dermatol 2002;29:638-43.

3. Winkelmann RK. Panniculitis in connective tissue disease. Arch Dermatol 1983;119:336-44.

4. Herane MI, Urbina F, Sudy E. Lipoatrophia semicircularis: a compressive lipoatrophy consecutive to persistent mechanical pressure. J Dermatol 2007;34:390-3.

5. Ogino J, Saga K, Tamagawa M, Akutsu Y. Magnetic Resonance Imaging of Semicircular Lipoatrophy. Dermatology 2004;209:340-1 